\title{
Students'Perceived Challenges in an Online Collaborative Learning Environment: A Case of Higher Learning Institutions in Nairobi, Kenya
}
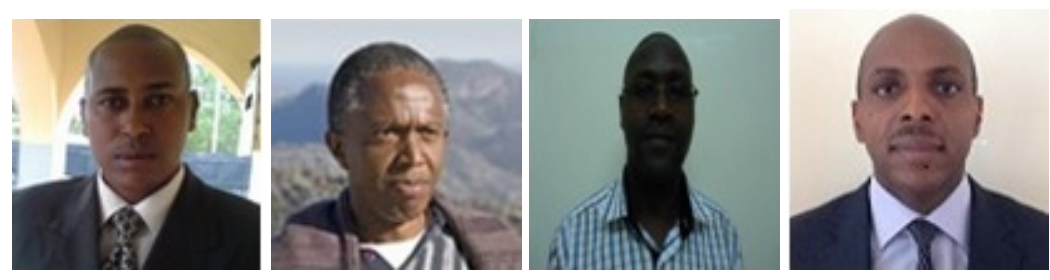

Maina Elizaphan Muuro' ${ }^{1}$, Waiganjo Peter Wagacha², Robert Oboko², and John Kihoro ${ }^{3}$ ${ }^{1}$ Kenyatta University, Kenya, ${ }^{2}$ University of Nairobi, Kenya, ${ }^{3}$ Co-operative University College, Kenya

\section{Abstract}

Earlier forms of distance education were characterized by minimal social interaction like correspondence, television, video and radio. However, the World Wide Web (WWW) and online learning introduced the opportunity for much more social interaction, particularly among learners, and this has been further made possible through social media in Web 2.0. The increased availability of collaborative tools in Web 2.0 has made it possible to have online collaborative learning realized in Higher Learning Institutions (HLIs). However, learners can perceive the online collaborative learning process as challenging and they fail to utilize these collaborative tools effectively. Although a number of challenges have been mentioned in the literature, considerable diversity exists among countries due to diversity in infrastructure support for e-learning and learners' background. This motivated this study to investigate components of online collaborative learning perceived as challenging by learners in HLIs in Kenya. Using a questionnaire, a survey was conducted in two public universities and two private universities to identify students' perceived challenges in an online collaborative learning environment. Through purposive sampling the questionnaire was distributed to 210 students using e-mail and 183 students responded. Based on descriptive analysis the following five major challenges were rated as high: lack of feedback from instructors, lack of feedback from peers, lack of time to participate, slow internet connectivity, and low or no participation of other group members. There was also a relationship between the university type (private or public) with the perceived challenges which included: lack of feedback from the instructor $(\boldsymbol{p}=0.046)$ and work load not shared equally among group members $(\boldsymbol{p}=0.000)$. Apart from slow internet connectivity the rest of the challenges were in line with the observed challenges in the 
literature.These key challenges identified in this study should provide insight to educators on the areas of collaborative learning that should be improved in order to provide access to quality education that supports effective online collaborative learning in HLIs in Kenya.

Keywords: Social interaction; Web 2.0; online collaborative learning; perceived challenges; collaborative tools; HLIs in Kenya

\section{Introduction}

With the increased demand of higher education in Kenya, e-learning in Kenya has gained popularity. To meet the growing demand most of the Kenyan universities have set up an e-learning portal to tap the many students who do not have time to attend physical classes but have time to study online. For example to address the increased demand for e-learning programs in Kenya, recently Kenyatta University (KU) launched a digital school. According to KU website, the digital school offers over 100 courses through blended learning. The students taking these courses can access notes and assignments on the e-learning portal and later they attend four hour face-to-face tutorials for every course before they sit for the final exam. Consequently, other universities in Kenya have followed the same suite and now have e-learning portals for blended learning.

With the recent installation of fiber optic cables in Kenya, the cost for internet has dropped. For example in Nairobi, one can access fiber optic speed of about $100 \mathrm{mbps}$ at US \$12 per month. According to Karshoda and Waema (2014), about 52\% of the students in Kenyan universities own smartphones and 53\% own laptops. This shows increased ownership, which coupled with decreased internet access cost means that universities have a good opportunity to offer distance education as well as blended elearning through technology enhanced pedagogies. This recent e-readiness survey which was carried out in 17 Kenyan universities indicated that student population doubled within a period of five years, as shown in Table 1. Therefore, universities should increase their internet bandwidth expenditures from the current $0.5 \%$ to $1.5 \%$ of their total annual expenditure by the year 2016 (Karshoda et al., 2014). This was good recommendation in terms of network access, however for distance learners to benefit from this bandwidth e-pedagogy challenges must also be addressed with concrete data within the Kenyan context. This research comes at a time when Kenyan universities are now aware of their e-readiness status in terms of: network access, networked campus, networked learning, networked society, and institutional ICT strategy as defined by Karshoda et al. (2014), and the same time they are being faced with the increased demand in higher education. Therefore, technology enhanced teaching and learning approaches is no longer an option but a requirement to meet this increased demand. Consequently, the government of Kenya has recommended the establishment of 
National Open University of Kenya by December 2014, in an effort to expand enrolment through distance and e-learning. With all this information at hand, there is need to explore other elements in e-learning like collaborative learning which has pedagogical advantages such as development of critical thinking skills, co-creation of knowledge and meaning, reflection and transformative learning (Palloff \& Pratt, 2005).

Table 1

Demographic Data and Internet Availability for 17 Universities in Kenya From 20082013

\begin{tabular}{|l|l|l|l|l|l|l|}
\hline $\begin{array}{l}\text { Year } \\
\text { of } \\
\text { survey }\end{array}$ & $\begin{array}{l}\text { Total } \\
\text { students }\end{array}$ & $\begin{array}{l}\text { Total } \\
\text { PCs } \\
\text { owned } \\
\text { by } \\
\text { students }\end{array}$ & $\begin{array}{l}\text { Total } \\
\text { bandwidth } \\
(\mathrm{Mb} / \mathrm{s})\end{array}$ & $\begin{array}{l}\text { Bandwidth } \\
\text { per 1,000 } \\
\text { students }\end{array}$ & $\begin{array}{l}\text { PCs per } \\
100 \\
\text { students }\end{array}$ & $\begin{array}{l}\text { \% of students } \\
\text { with PCaccess at } \\
\text { home }\end{array}$ \\
\hline 2008 & 162,319 & 8,907 & 70.8 & 0.436 & 5.5 & 27 \\
\hline 2013 & 339,418 & 13,815 & $1,431.5$ & 4.22 & 4.07 & 30.4 \\
\hline
\end{tabular}

Source: KENET e-readiness data in 2008 and 2013

Some universities in Kenya have embraced the use of technology in teaching and they have established institutes like Open, Distance and e-Learning (ODeL) which coordinate distance learning programmes, develop e-content and build capacity in elearning through training staff on e-learning pedagogies and establishing centers which have computer labs where distance learners can access learning materials and the same time they can do collaborative learning online. The government of Kenya has also established policies to guide ODeL in HLIs which recommends the establishment of an open university as contained in Sessional Paper No. 1 of 2005 (Republic of Kenya, 2005). This is further indication of the government initiative to support ODeL programs to meet the increased educational demand in HLIs in Kenya. Despite this support, previous research in two Kenyan universities (University of Nairobi [UoN] and KU) has identified some key challenges in delivery of ODeL like lack of e-learning resources, higher level of students' dissatisfaction (90.8\%) and lecturers' dissatisfaction (85.6\%) with the programme organization and delivery (Nyerere, Gravenir \& Mse, 2012). Given these two universities are pioneers in ODeL, these challenges could also be hindering effective implementation of ODeL programs in other HLIs in Kenya. However, this research did not address the use of collaborative tools in e-learning platforms and the related challenges which should go in line with the effective implementation of ODeL programs to realize the full potential of e-learning.

Although there are many e-learning platforms in Kenya the most popular ones are Moodle and Blackboard which do provide both synchronous and asynchronous 
collaborative tools. Using these e-learning platforms, learners are able to follow lectures online, interact with lecturers, start online discussions through various collaborative tools, submit assignments and check on their academic progress online. Despite the potential benefits of collaborative learning, like development of critical thinking skills, co-creation of knowledge and meaning, reflection and transformative learning, these collaborative tools are yet to be put into full utilization as according to Nyerere et al. (2012), most of the instructors use the e-learning platforms to communicate to their students, for instance posting course notes or sending them assignments. However some private universities in Kenya such as Strathmore University and Australian University Study Institute (AUSI) have adopted the use of e-learning in more than $80 \%$ of their courses through the Moodle platform while public universities such as KU has only managed to offer about $25 \%$ of their courses through the Moodle platform. This information is found on the universities' websites. This information shows that private universities have been utilizing e-learning platforms more than public universities. Therefore there is need to consider both public and private universities when investigating the key challenges associated with online collaborative learning in order to get concrete data which can be useful in both cases.

Previously, research has been carried out to investigate the learners' satisfaction (Singh, 2005), perceived usefulness and challenges (Song, Singleton, Hill \& Koh, 2004; Kim, Liu \& Bonk, 2005), and factors leading to unsuccessful group collaboration (Roberts \& McInnerney, 2007; Liu, Joy, \& Griffiths, 2010) in a collaborative online learning environment. However, results have shown that perceived challenges are likely to vary depending on type of e-learning technology used, infrastructure availability (internet and computers) and the use of different learner activity management systems (LAMSs) in HLIs. Furthermore, in Kenya no empirical evidence has been gathered to establish the perceived challenges in an online collaborative learning environment. The purpose of this study is to investigate students' satisfaction and perceived challenges in an online collaborative learning environment with specific attention to those LAMSs being utilized by HLIs in Kenya and more specifically in Nairobi, where e-learning infrastructure is more established in terms of network access due to fiber optic network and education demand being higher as compared with other regions in Kenya.

This study was conducted to investigate the components of online collaborative learning which learners perceive as challenging, hence hindering the effective collaboration process in their online group activities. These three primary questions guided this research design:

1. To what extent do students collaborate online while doing group work in HLIs in Kenya?

2. What are the components of online collaborative learning which learners perceive as challenging in HLIs in Kenya? 
3. Is there any significance relationship between university type (public or private) and the perceived challenges in using an online collaborative learning environment?

\section{Literature Review}

Like any other educational idea collaborative learning is an overloaded term with different meanings being given by different scholars. In our research study we adopt Dillenbourg's (1999) definition where collaborative learning is defined as a situation in which two or more people learn or attempt to learn something together. The situation is termed collaborative if peers are more or less at the same level, can perform the same actions, have a common goal and work together. In the pedagogy of teaching, teachers are encouraged to assign group work that gives students the freedom to learn from one another. The idea of group work in learning finds its root in work from the Russian psychologist Vygotsky (1978) who explored the causal relationships that exists between social interaction and individual learning providing a foundation of the social constructivist theory of learning.

Constructivist psychologists advocate the use of collaborative tools such as discussion forums in e-learning as they support the argument that cognitive development is a result of social interaction (Vygotsky, 1978; Siemens, 2005). Other researchers have also explored how constructivism and connectivism learning theories can be adequately used in education technology for the digital age (Mattar, 2010). A commonly used collaborative learning technique is the use of group work to learn a task and researchers have demonstrated that learning is more effective if peers collaborate and share ideas when solving a task as a group rather than as individuals (J ohnson and J ohnson, 1989). They also demonstrated that construction and synthesis of knowledge through group work outperforms individual learning (Brindley, Blaschke \&Walti, 2009; Moller, 1998). In their book, Harasim, Hiltz, Teles, and Turoff (1995) have fully demonstrated the potential of collaborative learning in distance education through learning networks which are used to create learning communities at a distance in which learners construct knowledge through active participation with peers and from experts wherever they are located. Learning in groups in an online context gives the students the opportunity to express their own ideas, negotiate meaning, and develop key professional skills like listening, presenting ideas, persuasion, self-direction, self-monitoring and team working (J aques \& Salmon, 2007).

This constructivism theory of learning has been adopted in HLIs in Kenya where students are engaged in discussions by tutorial fellows. These tutorials give the learners a chance to collaborate face to face, critique one another, share knowledge and compare new concepts with one another. Similarly, by introducing e-discussion forums in an online learning environment it is possible to have social affective and cognitive benefits realized in face-to-face tutorials. Effective strategies must be laid down to ensure 
students are not passive but they actively enter into the online classroom and post their thoughts and ideas to the online discussion (Palloff \& Pratt, 2007). Moreover, constructivism theory of learning can be supported in ODeL through a variety of technologies which support constructive learning like computer-mediated communication, computer supported collaborative work, case-based learning environments and computer-based cognitive tools (Jonassen, Davidson, Collins, Campbell \& Hagg, 1995). However, social interaction experienced in an online learning environment lacks the aspect of face-to-face interaction experienced in a classroom environment and there do exist notable differences like communication limitations due to lack of interaction support tools in real time, and absence of challenge and explain cycles of interaction that characterize face-to-face tutorials (Curtis \& Lawson, 2001). This gives online learning a major disadvantage even though its demand continues to rise. Consequently online collaborative learning becomes more challenging than face to face prompting the need to carry out more empirical research to identify the key challenges and provide mechanisms to address them in order to realize the same benefits as in face to face collaborative learning.

The Kim et al. (2005) study on an MBA online course reveals that even when students had positive attitudes towards online learning because of its benefits (flexibility, more learning experience through social interaction and enhancement of virtual teaming skills) they are faced with some challenges such as difficulty in communication with peers, lack of sense of community and absence of real-time feedback. Existence of these challenges is an indication that learners in this course could not realize the benefits of collaborative learning. In their study, Roberts and McInnerney (2007) identified seven common problems in an online learning environment: student antipathy towards group work, selection of the groups, lack of essential group-work skills, free-rider, possible inequalities of students' abilities, withdrawal of group members and assessment of individuals within the groups. Zorko (2009) investigated factors which inhibit collaboration in wikis and the study provided recommendations on how to increase collaborative behaviors in the wiki in problem based English language learning. Studies have also shown that online learners get frustrated with collaborative learning due to commitment imbalance on the task and lack of common learning goals among students hence requiring the instructor to equip online learners with social and group skills necessary for effective collaboration (Capdeferro \& Romero, 2012). Table 2 summarizes some of these perceived challenges within three categories: poor motivation, lack of individual accountability and negative interdependence (Liu et al., 2010). This summary review provides the background for conceptual elements which needed to be examined as challenging from students' perspectives. 
Table 2

Perceived Challenges in Online Collaborative Learning Environment

\begin{tabular}{|c|c|c|}
\hline Category & Description & Source \\
\hline Poor Motivation & $\begin{array}{ll}\text { - } & \text { Posting irrelevant posts to the learning } \\
\text { - } & \text { Misunario } \\
\text { - } & \text { Posts containing grammatical/spelling } \\
\text { - } & \text { Difficulty in communication with peers } \\
\text { - } & \text { Absence of real-time feedback } \\
\text { - } & \text { Disagreement among members } \\
\text { - Withdrawal of group members } \\
\text { - Assignments of students to group } \\
\text { - } \text { membership } \\
\text { - } \quad \text { Lack of common learning goals among } \\
\text { students }\end{array}$ & $\begin{array}{l}\text { (Liu et al., 2010; } \\
\text { Hassanien, 2007; } \\
\text { Black, 2005; } \\
\text { Capdeferro et al., } \\
\text { 2012) }\end{array}$ \\
\hline $\begin{array}{l}\text { Lack of Individual } \\
\text { Accountability }\end{array}$ & $\begin{array}{ll}\text { - } & \text { Not contributing much } \\
\text { - } & \text { Lack of time } \\
\text { - } & \text { Too lazy to work and not meeting } \\
\text { deadline } \\
\text { - Free-rider } \\
\text { - Lack of individuals assessment within } \\
\text { the groups }\end{array}$ & $\begin{array}{l}\text { (Kim et al. 2005; } \\
\text { Liu et al., 2010; } \\
\text { Singh, 2005) }\end{array}$ \\
\hline $\begin{array}{l}\text { Negative } \\
\text { Interdependence }\end{array}$ & $\begin{array}{ll}\text { - } & \text { Lack of essential group-work skills } \\
\text { - } & \text { Lack of sense of community } \\
\text { - } & \text { Possible inequalities of students' } \\
\text { - } & \text { Singilities } \\
& \text { scenario } \\
\text { - } & \text { Unwillingness to criticize } \\
\text { - } & \text { Little feedback on each other's work } \\
\text { - } & \text { Commitment imbalance on the task } \\
\text { - } & \text { Poor group management }\end{array}$ & $\begin{array}{l}\text { (Liu et al., 2010; } \\
\text { Roberts et al., } \\
\text { 2007; } \\
\text { Capdeferro et al., } \\
\text { 2012; } \\
\text { Zorko, 2009) }\end{array}$ \\
\hline
\end{tabular}

Although most of these challenges are common across the studies, there could be diversity in some cases due to infrastructure availability (like network access, computermediated communication tools and instructor support) and student background in different HLIs. To bridge this diversity gap there is need to carry out more surveys on the perceived challenges in those countries where these studies are yet to be done. Therefore, there is a need to empirically investigate the students' perceived challenges in an online collaborative learning environment in HLIs in Kenya. This will provide further insights to online instructors in HLIs in Kenya who would like to include constructivist pedagogy in e-learning on the status in the use of computer-mediated communication tools for collaborative learning and the same time inform them of the 
existing challenges. This also provides an opportunity to researchers to find relevant solutions to these challenges when paying particular attention to Kenya. This study comes at a time when HLIs in Kenya have witnessed increased enrollment within constrained physical resources; consequently, they have adopted blended e-learning through ODeL programs to complement the scarce physical resources (Nyerere et al., 2012). Status on collaborative learning in HLIs in Kenya is yet to be established definitely; this research provides an opportunity to inform instructors and learners with concrete data on the status and the associated key challenges in an online collaborative learning environment in HLIs in Kenya.

\section{Methodology}

\section{Research Design}

A cross-sectional study using descriptive survey was used to investigate students' collaboration level in group work and identify students' perceived challenges in an online collaborative learning environment. A descriptive survey was adopted as it could examine the situation the way it is and provide quantitative information that was summarized through statistical analyses, thus providing the basis to answer our research questions (Engelhart, 1972). This survey was conducted by administering questionnaires using a web-based tool (Lime survey). This approach was preferred because it enabled a faster collection of responses and the ease of exporting the data to our Statistical Package for Social Sciences (SPSS) for analysis.

\section{Sample and Sampling Procedures}

Purposive sampling was adopted to select two public universities namely KU and J omo Kenyatta University of Science and Technology (J KUAT), and two private universities namely United State International University (USIU) and AUSI, which have adopted the use of online collaborative learning tools in their e-learning modules and they are within Nairobi. Purposive sampling was also used to select students who were engaged in group activities online. With the help of instructors a total of two hundred and ten students were identified within the four universities. These were students who were undertaking at least one course or a module online on an e-learning platform. The sampled students were informed by their instructors of the purpose of the study, and responding to the questionnaire items was voluntary.

\section{Research Instruments}

Data was collected through a questionnaire that consisted of thirty items. The literature review provided the conceptual elements which were used to develop the set of items in 
the questionnaire. Twenty nine items in the questionnaire were close ended while one item was open ended. Table 3 summarizes the different categories for the questionnaire items. To ensure validity, content related evidence was used and two experts in elearning were requested to review the content and the format of the instrument. From their comments some items were rephrased, some content in group orientation added and reformatting done as recommended. Content-related evidence was adopted to ensure the instrument contained an adequate sample of the key challenges related to online collaborative learning (Fraenkel, Wallen \&Hyun, 2012).

Table 3

Summary of the Questionnaire Items

\begin{tabular}{|c|c|c|}
\hline Item Number & Type & Information gathered \\
\hline Items 1-7 & $\begin{array}{l}\text { Multiple } \\
\text { choice }\end{array}$ & Demographic information \\
\hline Item 8 & $\begin{array}{l}\text { Multiple } \\
\text { choice }\end{array}$ & $\begin{array}{l}\text { Gadgets used by students to access online } \\
\text { materials }\end{array}$ \\
\hline Item 9 & Likert Scale & $\begin{array}{l}\text { How often a collaborative tool is used to do } \\
\text { collaborative work }\end{array}$ \\
\hline Items $10-11$ & $\begin{array}{l}\text { Multiple } \\
\text { choice }\end{array}$ & $\begin{array}{l}\text { To filter students who had participated in an online } \\
\text { group activity so that they could proceed with item } \\
12 \text { up to } 30\end{array}$ \\
\hline Item 12 & $\begin{array}{l}\text { Multiple } \\
\text { choice }\end{array}$ & Frequency of use on the collaborative tools \\
\hline Items 13-21 & $\begin{array}{l}\text { Multiple } \\
\text { choice }\end{array}$ & $\begin{array}{l}\text { Group orientation in terms of how the groups were } \\
\text { formed, managed and students' satisfaction with } \\
\text { their group membership }\end{array}$ \\
\hline Item 22 & $\begin{array}{l}\text { Multiple } \\
\text { choice }\end{array}$ & Instructor's role during the group activity \\
\hline $\begin{array}{l}\text { Items } 23,24, \& \\
25\end{array}$ & $\begin{array}{l}\text { Multiple } \\
\text { choice }\end{array}$ & $\begin{array}{l}\text { Level of individual participation in the group } \\
\text { activity }\end{array}$ \\
\hline $\begin{array}{l}\text { Items } 22,26, \& \\
28\end{array}$ & $\begin{array}{l}\text { Multiple } \\
\text { choice }\end{array}$ & Student experiences during the group activity \\
\hline Items $27 \& 29$ & Likert Scale & $\begin{array}{l}\text { Student level of agreement on group work } \\
\text { challenges as observed from literature review. }\end{array}$ \\
\hline Item 30 & Open ended & $\begin{array}{l}\text { Students' worst experiences in an online group } \\
\text { activity from their own perspective }\end{array}$ \\
\hline
\end{tabular}

\section{Data Collection and Analysis}

The questionnaire was distributed through email invitations to the participants. The invitation email contained the purpose of the study and a link to the URL where the questionnaire was located. Each participant was given only one token to ensure single response to the questionnaire. The questionnaire was made available for a period of two weeks as most of the students did not respond immediately. A total of 183 students responded: This was an $87 \%$ response rate which was adequate for analysis. The 
collected data was exported to SPSS version 14 and coded as per the research objective. A quantitative analysis was carried out, such as frequencies and percentages on: demographic information, collaboration tools, level of access on group activity and students' perceptions on various aspects of group activity. Since the questionnaire items were meant for a bigger study, not all analysis has been included in this paper.

\section{Results}

\section{Participants' Demographic Information}

A total of 183 students responded out of 210 , with $44.9 \%$ from a private university and $53.5 \%$ from a public university while three respondents (1.6\%) did not provide university names. One respondent did not provide any demographic information including age and gender. Table 4 summarizes the demographic information.

Table 4

Demographic Information of the Sample $(\mathrm{N}=183)$

\begin{tabular}{llll}
\hline \multicolumn{2}{l}{ Characteristic } & Frequency & Percentage \\
\hline 1. & Age in bracket(at the time of & & \\
survey) & 108 & $59.0 \%$ \\
15-25 years & 59 & $32.2 \%$ \\
26-35years & 13 & $7.1 \%$ \\
36-45 years & 2 & $1.1 \%$ \\
46-55 years & 1 & $0.5 \%$ \\
N/A & & \\
Gender & 116 & $63.4 \%$ \\
Male & 66 & $36.1 \%$ \\
Female & 1 & $0.5 \%$ \\
N/A & & \\
University & 14 & $7.7 \%$ \\
AUSI (Private) & 50 & $27.3 \%$ \\
J KUAT (Public) & 48 & $26.2 \%$ \\
KU (Public) & 68 & $37.2 \%$ \\
USIU (Private) & 3 & $1.6 \%$ \\
No Answer & & \\
Level of Study & 14 & $7.7 \%$ \\
Certificate & 5 & $2.7 \%$ \\
Diploma & 21 & $11.5 \%$ \\
Postgraduate & 142 & $77.6 \%$ \\
Undergraduate & 1 & $0.5 \%$ \\
No Answer & & \\
Modules Studied online & 35 & $19.1 \%$ \\
2-3 modules & 27 & $14.8 \%$ \\
4-5 modules & 51 & $27.9 \%$ \\
More than five modules & 5 &
\end{tabular}




$\begin{array}{lll}\text { One module } & 68 & 37.2 \% \\ \text { No Answer } & 2 & 1.1 \% \\ \text { Internet Skills } & & \\ \text { Excellent } & 138 & 75.4 \% \\ \text { Good } & 32 & 17.5 \% \\ \text { Moderate } & 11 & 6.0 \% \\ \text { No Answer } & 2 & 1.1 \%\end{array}$

\section{Group Characteristics}

Two group characteristics were collected to determine how the students were assigned to group membership and the group sizes. As shown in Table 5, students were assigned to group membership in different ways and group sizes were also different. Out of 108 students who responded a higher percentage was done by the instructor (59\%), 16\% at random through default assignment in Moodle, 18\% self assignment and $7 \%$ were not aware how the assignment was done. The number of students in a group ranged from 2 to 5 (32\%), 6 to 10 (27\%) and more than 10 students (35\%). While 6\% were not aware of the number of students in their group. This shows that more than $50 \%$ of students discussed in groups of more than five students which is contrary to the recommended small group sizes of 2 to 5 students for effective group learning which enables each group member to express his/her own ideas and increases group cohesion (North, Linley, \& Hargreaves, 2000; Schellenberg, 1959; Forsyth, 2009)

${ }^{1}$ The level of access to internet services like emails, Chats, Facebook, Twitter, Telnet, Google Docs. etc. 
Table 5

Frequency on Group Assignment Method and Group Sizes

Group characteristics ( $\mathrm{n}=108)$

Frequency Percentage

1. Criteria used to assign group membership

Assigned by instructor

Default assignment in Moodle

64

I assigned myself

17

I don't know

19

8

$18 \%$

2. Number of members in a group

$7 \%$

2- 5 members

6-10 members

$34 \quad 32 \%$

More than 10 members

$29 \quad 27 \%$

I don't know

$6 \%$

\section{Popularity of Various Collaborative Tools}

As shown in Table 6 of all the respondents, $91.8 \%, 74.8 \%, 72.9 \%$ and $71.9 \%$ frequently use email, social media (Facebook and Twitter), telephone (mainly mobile phones), and chats respectively. Tools like Skype, video conference, workshops ${ }^{2}$ and podcasts ${ }^{3}$ had the lowest frequency of use, which is an indication that these tools are rarely used by students to collaborate online. Table 6 shows the percentage, mean ranking and standard deviation on the frequency of use on various collaboration tools.

${ }^{2}$ Peer assessment activity in Moodle

${ }^{3}$ Audio files created by students for peer learning 
Table 6

Frequency of Use on Various Collaborative Tools

\begin{tabular}{lcllll}
\hline Collaboration tool & $\mathrm{n}$ & Rarely & Often & Mean & Std. Deviation \\
\hline Emails & 182 & $8.2 \%$ & $91.8 \%$ & .92 & .276 \\
Social media & 182 & $25.2 \%$ & $74.8 \%$ & .75 & .436 \\
Telephone & 181 & $27.1 \%$ & $72.9 \%$ & .73 & .446 \\
Chats & 181 & $28.1 \%$ & $71.9 \%$ & .72 & .451 \\
Google Doc. & 180 & $47.2 \%$ & $52 . \%$ & .53 & .501 \\
Wikis & 178 & $65.8 \%$ & $34.2 \%$ & .34 & .476 \\
Forums & 181 & $67.4 \%$ & $32.6 \%$ & .33 & .470 \\
Skype & 182 & $72.5 \%$ & $27.5 \%$ & .27 & .448 \\
Video conference & 181 & $84.0 \%$ & $16.0 \%$ & .16 & .368 \\
Workshops & 178 & $84.3 \%$ & $15.7 \%$ & .16 & .365 \\
Podcasts & 178 & $93.8 \%$ & $6.2 \%$ & .06 & .241 \\
\hline
\end{tabular}

\section{Level of Collaboration in Various Collaborative Tasks}

Out of 183 students who responded only 108 students (59\%) indicated that they had done some group work online in their e-learning modules. The rest of the respondents (41\%) were not involved in an online group work for reasons which included: instructor not providing an online group activity (41.3\%), lack of time (29.3\%), lack of skills to participate in online discussion (12\%) and not enrolling to a group (17.3\%).

More than $80 \%$ of the respondents had very low access to posts and they were not replying to posts; only less than $20 \%$ accessed or replied to posts more than 4 times in a week. It was found that $39.8 \%$ of the respondents indicated that either they accessed or replied to posts only once in a week, $42.7 \%$ accessed the posts 2-3 times in a week, $48.5 \%$ replied to posts 2-3 times in a week. Table 7 summarizes the observed level of access and reply to posts. 
Table 7

Students' Level of Access and Reply to Post in an Online Group Activity (N=108)

\begin{tabular}{|c|c|c|c|c|}
\hline No. of times of accessing & Access to posts & & Sending ne & osts/replies \\
\hline $\begin{array}{l}\text { and sending posts to the } \\
\text { discussion forum }\end{array}$ & Frequency & Percent & Frequency & Percent \\
\hline Only once & 41 & $39.8 \%$ & 41 & $39.8 \%$ \\
\hline 2-3 times in a week & 44 & $42.7 \%$ & 50 & $48.5 \%$ \\
\hline 4-5 times in a week & 6 & $5.8 \%$ & 7 & $6.8 \%$ \\
\hline $\begin{array}{l}\text { More than five times in a } \\
\text { week }\end{array}$ & 12 & $11.8 \%$ & 5 & $4.9 \%$ \\
\hline
\end{tabular}

\section{Perceived Challenges}

The questionnaire item on the perceived challenges had nine key challenges which respondents were required to rate with a yes or no response. The study revealed that the majority of respondents (54\%) perceived that lack of participation by other members was a big challenge as most students lacked time to participate (53\%). The difference in skills or knowledge level among group members was not perceived as a big challenge (19\%). Table 8 shows the distribution of responses on the nine key challenges from 108 respondents. In addition to these nine key challenges, slow internet connectivity (30\%), disruptions from incompetent peers (3\%), lack of clarity on the posted work (2\%), freeriders (2\%), no consensus on the discussions (3\%) and no original ideas posted (5\%) were also mentioned by respondents as some of their worst experiences during their group work. For example, participant number 9 stated: "My worst experience was when the internet was not consistent and it kept on logging users ON and OFF; and we ended up wasting almost one hour without active participation".

To establish whether there was any relationship between the type of university (public or private) and the perceived challenge chi-square test of independence was done. Table 9 summarizes the results of the chi-square test and the corresponding $p$ values. Statistical significance association was found only in two cases: lack of feedback from instructor ( $p=.041$ ) and work load not shared equally ( $p=.000$ ). 
Table 8

Mean Ranking and Standard Deviation for the Nine Key Challenges as Perceived by the Respondents $(\mathrm{N}=108)$

\begin{tabular}{lcl}
\hline Challenges & Mean & $\begin{array}{l}\text { Std. } \\
\text { Deviation }\end{array}$ \\
\hline Low or no participation of other group & .54 & .501 \\
members & .53 & .502 \\
Lack of time to participate & .47 & .502 \\
Lack of feedback from instructor & .43 & .497 \\
Lack of feedback from peers & .31 & .463 \\
Off-topic posts in the discussion & .27 & .445 \\
Work load not shared equally & .25 & .435 \\
Lack of group mentor & .25 & .435 \\
Single student dominating & .19 & .390 \\
Difference in skill/knowledge level among & & \\
group members
\end{tabular}

Note. The mean is equivalent to the proportion of yes responses in the above table.

Table 9

Associations Between University Type (Private or Public) and the Perceived Challenges in Using Online Collaborative Learning Environment

\begin{tabular}{lll}
\hline Perceived Challenge & $x^{2}$ & $p$ \\
\hline Low or no participation of other group members & 0.255 & 0.613 \\
Lack of time to participate & 0.400 & 0.527 \\
Lack of feedback from instructor & 4.176 & $0.041^{*}$ \\
Lack of feedback from peers & 0.844 & 0.358 \\
Off-topic posts in the discussion & 0.000 & 0.990 \\
Work load not shared equally & 12.802 & $0.000^{*}$ \\
Lack of group mentor & 1.913 & 0.167 \\
Single student dominating & 0.004 & 0.947 \\
Difference in skill/knowledge level among group members & 0.179 & 0.672
\end{tabular}

$* p<0.05$ 


\section{Discussion}

First, the study aimed to investigate how often students collaborate online while engaging in group work in HLIs in Kenya. The findings indicate that out of 183 respondents who were doing a module/ unit through e-learning, only 108 students (59\%) were engaged in an online group activity, while 75 students (41\%) were not involved in an online group work. The study found that failure of the instructor to provide an online group activity contributed highly to non participation in collaborative learning. Moreover, for those who participated in group work, $47 \%$ mentioned that they perceived lack of feedback from the instructor as a big challenge. This was an indication online instructors were not fully engaging students in collaborative learning in blended e-learning programs. This could be due to the known situation that in most HLIs in Kenya, instructors use e-learning platforms to send notes and assignments, are heavily burdened with many duties and lack skills in e-pedagogy (Nyerere et al., 2012). The study also found that for those who were engaged in collaborative work the level of collaboration was very low as most of the respondents (90\%) accessed the discussion forum less than two or three times in a week. Consequently the rate of posting to the discussion forum was found to be very low with only $11.7 \%$ of the respondents sending an average of 4 to 5 posts in a week. The findings revealed that students in these HLIs do not often collaborate online. Hence, there is a need to hire more trained instructors or train the current instructors who can engage students in an online collaborative work and create time to monitor their participation.

Secondly, the study aimed to investigate the components of online collaborative learning which learners perceive as challenging in HLIs in Kenya. In this study it was found that $54 \%$ strongly perceived that lack of participation by other members was a big challenge. This could be supported by the factor that $53 \%$ also responded they did not have time to participate. Lack of feedback both from instructor and peers was also perceived as a challenge by $47 \%$ and $43 \%$ respectively. This concurred with results from other researchers who found that low participation by members and lack of feedback both from instructor and peers was a major hindrance to collaborative learning (Liu et al., 2010; Capdeferro et al., 2012; Kim et al., 2005). Although Roberts et al. (2007) identified seven common problems, contrary to this study the problems were not major as few respondents were in agreement. Furthermore, 30\% of the participants mentioned slow internet connectivity as one of their worst experiences even though previous research had not captured it. This could be due to low internet bandwidth $(4.22 \mathrm{Mb} / \mathrm{s}$ per 1,000 students) availed to students in Kenyan Universities (Karshoda et al., 2014). This was somewhat surprising given that the study was conducted in Nairobi where internet infrastructure is far better than other regions in Kenya where fiber optic network is yet to be established. This implies that for other regions the problem will be more critical. Therefore, in order to maximize the use of e-learning platforms we do concur with Karshoda et al. (2014) in their e-readiness report to have HLIs in Kenya invest more in campus backbone and wireless network infrastructure to increase the level of internet availability to students. 
Thirdly, there was significant difference between the public and the private university in terms of lack of instructor feedback $(\mathrm{p}=0.046)$ and workload not shared equally $(\mathrm{p}=$ 0.000). The study found that lack of instructor feedback as a challenge was reported more in public universities (31\%) than in private universities (16\%). This could be due to the big numbers of students enrolled per class in public universities which makes the instructor to student ratio higher than in private universities. Consequently, the instructors in public universities are overloaded with work and this could have affected the low level of feedback observed. The study also found that the challenge of workload not shared equally among the students in an online collaborative learning group was reported to be higher in private universities (20\%) than in public universities (7\%). This seems to support the perception that students in public universities are more independent, working with minimal instructor supervision, which probably gives them an advantage to work more cohesively in group work. This requires further investigation to establish why such a significant difference existed.

\section{Conclusion}

Despite the potential advantages in collaborative learning, this study reveals that lack of participation among group members and lack of feedback from instructors are major hindrances to effective online collaboration in HLIs in Nairobi, Kenya. This coincides with other studies in other regions(Liu et al., 2010; Capdeferro et al., 2012; Kim et al., 2005). Furthermore, some instructors did not include collaborative learning activities in their online courses and therefore $41 \%$ of the participants were not engaged in collaborative learning. Therefore, further research should also be carried out to investigate instructors' level of awareness, utilization and perceived challenges of online collaborative learning tools which are available in e-learning platforms. This could also shed more light on how to improve the quality of online collaborative learning in HLIs in Kenya. We do also concur with Karshoda et al. (2014) that internet bandwidth should be increased in HLIs in Kenya in order to avoid the challenge of slow internet connectivity as reported by $30 \%$ of the participants in this study. In order to make collaborative learning more effective in these HLIs the researchers do recommend that institutions should:

- Ensure their instructors do engage students in collaborative activities in their online courses and instructor's role is more emphasized during collaborative learning

- Find ways of motivating the students in order to increase their level of participation in collaborative learning

- Find ways of motivating the instructors in order to make them more active in monitoring students' collaboration and come up with 
mechanisms of training instructors with e-pedagogy skills which can enhance collaborative learning

- Find ways of increasing internet bandwidth in order to avail more bandwidth to students who are studying online.

\section{Future Work}

Similar future studies should adopt large scale empirical approaches, within different universities or geographical regions in Kenya in order to confirm some of the findings observed here in other universities and also to be able to generalize the results to the larger population of Kenyan universities. Future studies could also consider examining the effectiveness of collaborative learning in enhancing students' critical thinking skills and improving the level of knowledge constructed in blended e-learning platforms.

\section{Acknowledgements}

The authors appreciatively thank the National Commission for Science and Technology in Kenya for the financial support provided to facilitate data collection and analysis. The authors would also like to thank all the students in Kenyatta University, J omo Kenyatta University of Science and Technology, United State International University (Kenya) and Australian University Study Institute (Kenya) who willingly agreed to participate in this study and their instructors for facilitating the collection of the data. 


\section{References}

Black, A. (2005). The use of asynchronous discussion: Creating a text of talk. Contemporary Issues in Technology and Teacher Education, 5(1), 5-24. Retrieved on 20th August 2014, from http:// www.citejournal.org/articles/v5illanguagearts1.pdf

Brindley, J ., Blaschke, L. M., \&Walti, C. (2009). Creating effective collaborative learning groups in an online environment. The International Review of Research in Open and Distance Learning, 10(3). Retrieved on J anuary 5th 2014, from http:// www.irrodl.org/index.php/irrodl/article/ view/675/ 1271

Capdeferro, N., \& Romero, M. (2012). Are online learners frustrated with collaborative learning experiences? The International Review of Research in Open and Distance Learning, 13(2), 26-44. Retrieved on J anuary 5th 2014, from http:// www.irrodl.org/ index.php/irrodl/article/view/ 1127

Curtis, D. D., \&Lawson, M. J . (2001). Exploring collaborative online learning. J ournal of Asynchronous Learning Networks, 5(1), 21-34. Retrieved on 20th August 2014, from http:// wikieducator.org/images/6/60/ALN_Collaborative_Learning.pdf

Dillenbourg, P. (1999). What do you mean by collaborative learning?. Collaborativelearning: Cognitive and Computational Approaches, 1-19.

Engelhart, M.D. (1972). Methods of educational research. Chicago: Rand McNally.

Forsyth, D. R. (2009). Group dynamics. Belmont, CA: Wadsworth Cengage Learning.

Harasim, L., Hiltz, S. R., Teles, L., \&Turoff, M. (1998). Learning networks: A field guide to teaching and learning online. Cambridge, MA/London, England: The MIT Press.

Hassanien, A. (2007). A qualitative student evaluation of group learning in higher education. Higher Education in Europe, 32(2-3), 135-150. Retrieved on 30th July 2014 from http:// www.tandfonline.com/doi/pdf/ 10.1080/03797720701840633

Fraenkel, J . R., Wallen, N. E., \& Hyun, H. H. (2012). How to design and evaluate research in education. New York, N.Y: McGraw-Hill Higher Education.

J aques, D., \& Salmon, G. (2007). Learning in groups: A handbook for face-to-face and online environments ( $4^{\text {th }}$ ed.). UK, USA, and Canada: Routledge. 
Johnson, D. W., \&J ohnson, R. T. (1989). Cooperation and competition: Theory and research. Edina, MN: Interaction Book Company. Retrieved on $15^{\text {th }}$ August 2013, from http:// www.co-operation.org/ books-and-materials/

J onassen, D., Davidson, M., Collins, M., Campbell, J ., \&Haag, B. (1995). Constructivism and computer mediated communication in distance education. American J ournal of Distance Education, 9(2), 7-25. Retrieved on 20th August 2014, from http:// www.c3l.uni-oldenburg.de/ cde/ media/readings/jonassen95.pdf

Kashorda, M., \&Waema, T. (2014). E-readiness survey of Kenyan universities (2013) report. Nairobi: Kenya Education Network. Retrieved on $20^{\text {th }}$ August 2014, from http:/ / ereadiness.kenet.or.ke:8080/ ereadiness/2013/Ereadiness $\% 202013 \% 20$ Survey\%20of\%20Kenyan\%20Universities_FINAL.pdf

Kim, K. J ., Liu, S., \& Bonk, C. J . (2005). Online MBA students' perceptions of online learning: Benefits, challenges, and suggestions. The Internet and Higher Education, 8(4), 335-344.

Liu, S., J oy, M., \& Griffiths, N. (2010, J uly). Students' perceptions of the factors leading to unsuccessful group collaboration. In Advanced Learning Technologies (ICALT), 2010 IEEE 10th International Conference on (pp. 565-569). Sousse, Tunisia, 5-7 J uly 2010.

Mattar, J . A. (2010). Constructivism and connectivism in education technology: Active, situated, authentic, experiential, and anchored learning. Technology, 1-16.

Moller, L. (1998). Designing communities of learners for asynchronous distance education. Educational Technology Research and Development, 46(4), 115-122.

North, A. C., Linley, P. A., \& Hargreaves, D. J . (2000). Social loafing in a co-operative classroom task. Educational Psychology, 20(4), 389-392. Retrieved on 30th July 2014 from http:// www.pgce.soton.ac.uk/IT/ Research/Papers/Northetal2000SocialLoafin g.pdf

Nyerere, J . A., Gravenir, F. Q., \& Mse, G. S. (2012). Delivery of open, distance, and elearning in Kenya. The International Review of Research in Open and Distance Learning, 13(3), 185-205.

Palloff, R. M., \& Pratt, K. (2005). Collaborating online: Learning together in community. San Francisco, CA: J ossey-Bass.

Palloff, R. M., \& Pratt, K. (2007). Building online learning communities: Effective strategies for the virtual classroom. J ohn Wiley \& Sons. 
Republic of Kenya (2005). A policy framework for education, training and research: Meeting the challenges of education, training and research in Kenya in the 21st century. Nairobi: Government Printers.

Roberts, T. S., \& McInnerney, J . M. (2007). Seven problems of online group learning (and their solutions). Educational Technology \& Society, 10(4), 257-268.

Schellenberg, J . A. (1959). Group size as a factor in success of academic discussion groups. The J ournal of Educational Sociology, 33(2), 73-79. Retrieved on 30th J uly 2014, from http:// www.jstor.org/ stable/2264459

Siemens, G. (2005). Connectivism: A learning theory for the digital age. International J ournal of Instructional Technology and Distance Learning, 2(1), 3-10.

Singh, H. K. (2005). Learner satisfaction in a collaborative online learning environment. Retrieved on $26^{\text {th }}$ J anuary 2006, from http:/ / asiapacificodl.oum.edu.my/C33/F239.pdf

Song, L., Singleton, E. S., Hill, J . R., \& Koh, M. H. (2004). Improving online learning: Student perceptions of useful and challenging characteristics. The Internet and Higher Education, 7(1), 59-70.

Vygotsky, L. S. (1978). Mind in society: The development of higher psychological processes. Cambridge, UK: Harvard University Press.

Zorko, V. (2009). Factors affecting the way students collaborate in a wiki for English language learning. Australasian J ournal of Educational Technology, 25(5), 645-665. 


\section{Appendix}

\section{Questionnaire}

Online collaborative learning: Students perceptions

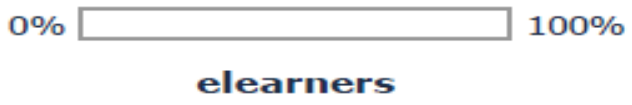

Gender

Female $\quad$ Male

What is your age bracket?

Choose one of the following answers

15-25 years

26-35 years

36-45 years

46-55 years

56 years and above

Which level of study are you currently in? Indicate the programme you have enrolled in e.g. Bsc. maths, BIT, DIT, etc on the comments side.

Choose one of the following answers
PostGraduate
- Undergraduate
- Diploma
- Certificate
- Short Course

Please enter your comment here:

In which university are you currently studying or did you take an online course?

Choose one of the following answers

- Jomo Kenyatta University of Science and Technology

- Kenyatta University

Strathmore University

USIU

AUSI 
Rate your internet skills

Choose one of the following answers

- Moderate (I know how to access emails and browse)

- Good(I know how to access emails, browse and download materials online)

- Excellent (I know how to access emails, browse, download materials and use Social media ) How many modules/ units have you ever studied online?

Choose one of the following answers

- One module

2-3 modules

- 4-5 modules

- more than five modules why did you choose to undertake an online unit/module

Check any that apply

It was cheaper than other modes

Darent/sponsor insisted

My ICt skills are well polished

Dy work schedule cannot allow other modes

(My home location is not favourable for modes

[It was a university requirement

Other(Please specify) Which gadgets do you (did you) use to access learning materials online? Comment on the right side why you prefer to use the gadget.

\section{Check any that apply}

- My Mobile

Phone and

Bundles

D My

Desktop/LapTop

and Bundles 


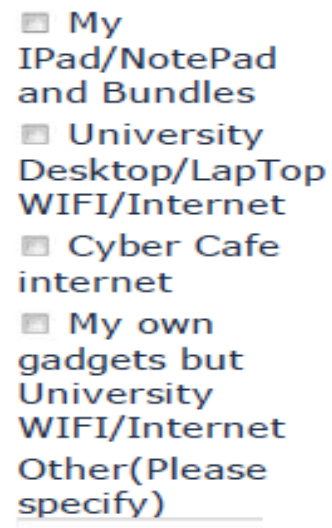

\begin{tabular}{|c|c|c|c|c|c|}
\hline & $\begin{array}{l}\text { Very } \\
\text { Often }\end{array}$ & Often & Sometimes & Rarely & Never \\
\hline Forums & 0 & 0 & 0 & 0 & 0 \\
\hline Wikis & 0 & 0 & 0 & 0 & 0 \\
\hline Workshops & 0 & 0 & 0 & 0 & 0 \\
\hline $\begin{array}{r}\text { Social } \\
\text { Medial(Face } \\
\text { book, } \\
\text { Twitter, } \\
\text { etc) }\end{array}$ & $\theta$ & 0 & 0 & 0 & 0 \\
\hline emails & 0 & 0 & 0 & 0 & 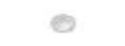 \\
\hline Skype & 0 & 0 & 0 & 0 & 0 \\
\hline $\begin{array}{r}\text { Video } \\
\text { Conference }\end{array}$ & 0 & 0 & $\theta$ & 0 & 0 \\
\hline PostCads & 0 & 0 & 0 & 0 & 0 \\
\hline Google Doc & $\theta$ & 0 & 0 & 0 & 0 \\
\hline Chats & 0 & 0 & 0 & 0 & 0 \\
\hline Telephone & 0 & 0 & 0 & 0 & 0 \\
\hline
\end{tabular}

Have you ever discussed a group activity online?

- Yes 0 No 
Which group discussion/communication tool do you use most to discuss group activities?

Choose one of the following answers

- Forums

Workshops

Wiki

Chats

emails

Video Conference

- skype

Podcast

- Google Doc

- Social media(Facebook, Twitter, etc.)

- Telephone

Other(Please specify)

which criteria was used to asssign you to group membership in your recent group activity

\section{Choose one of the following answers}

- I assigned myself

- Assigned by Instructor

- Default assignment in Moodle

I dont know

How many members were in your group?

Choose one of the following answers

2- 5 members

5-10 members

- More than 10 members

I dont know

How many group activities did you do in your unit/ module?

Only numbers may be entered in this field 
$*$

Did your group membership change during the study of the unit/module?

Yes 0 No

Was there a moderator/Mentor for the discussion in your group activity

- Yes No

Were you comfortable with the team members in your group?

- Yes 0 No

Which role did the instructor play during the discussion period in your group activity?

Check any that apply

- Encouraged learners to interact with one another

Rewarded thoughtful contributions

E Summarized key concepts

Moderated the discussions(policing and enforcing discussion rules and policies )

Intervened when conflict arose

Intervened when we were stack on an isssue

Discouraged personal criticism

Discouraged off topic posts

Rated the discussion

Provided timely feedback

Played no role

Dther(Please specify)

$*$

On average how many times were you accessing the discussion posts in a week?

Choose one of the following answers

O Once in a week 
2-3 times in a week

- 4-5 times in a wek

- More than five times in a week

On average how many post did you send to your group activity in a week?

\section{Choose one of the following answers}

Only Once

2-3 times in a week

4-5 times in a wek

- More than five times in a week

How quickly were you responding to posts related to the discussion forum in your group activity?

Choose one of the following answers

Never Responded

- Responded with some delay

Immediately

During the discussion period with your peers in your group activity, which among the following happened?

\section{Check any that apply}

I got a feedback every time i posted an idea

च I was informed about my participation status from time to time

My contributions were rated by the peers

I I was informed about my individual score

I was adviced how to improve my particiaption

by the instructor

II replied to all posts

I I challenged my peers contributions

I I read all messages/posts from my peers

The group activity improved my understanding on the topic under discussion

Wome members of the group never contributed

Other(Please specify) 
Indicate you opinion in the following issues:

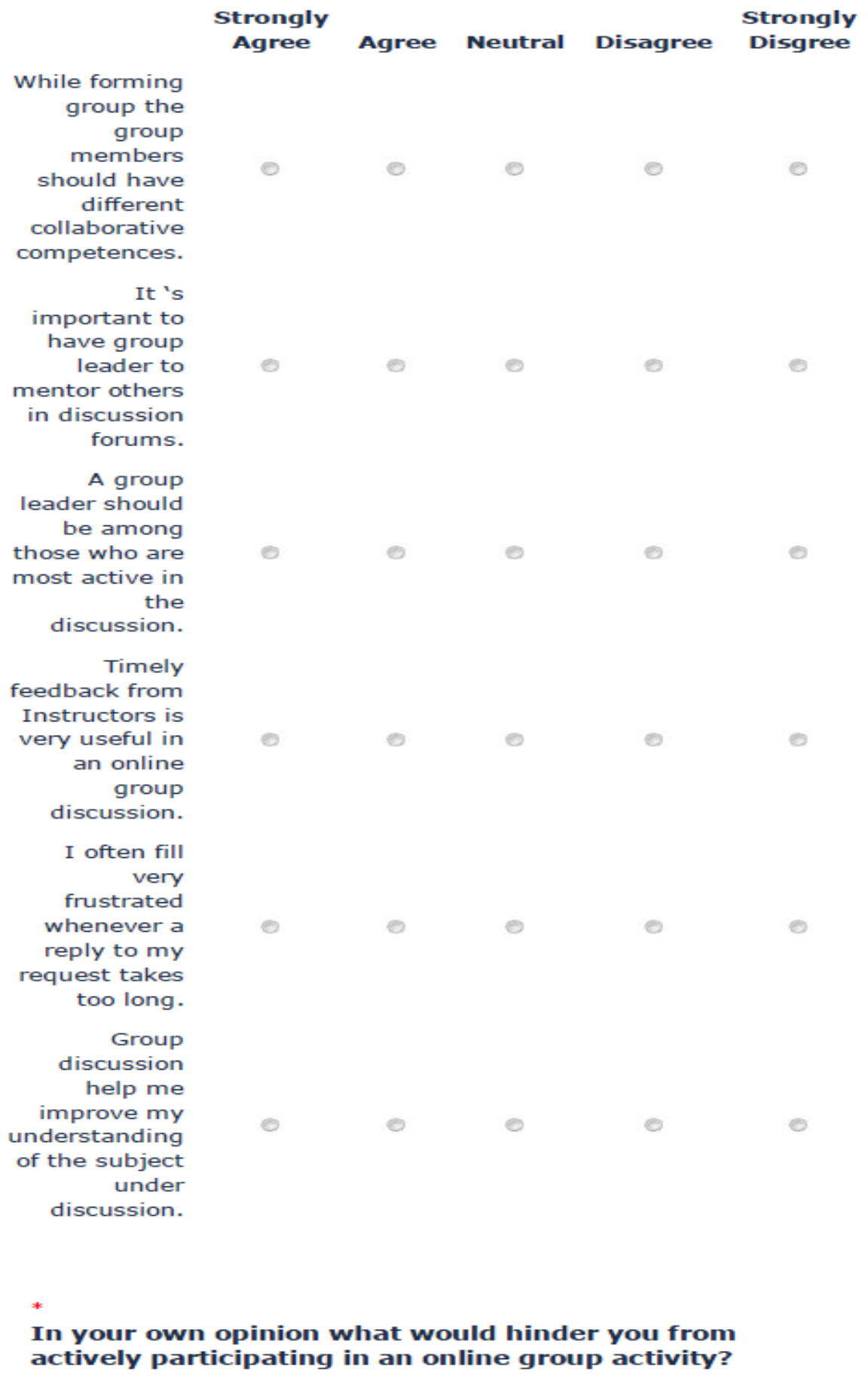




\section{Check any that apply}

Lack of feedback from peers

[1] Lack of feedback from instructor

[ Differences in skill/knowledge level of group members

Low or no participation of other group members

Workload not shared equally

[ Off-topic posts in the discussion

Wingle student dominating the group discussion

- Lack of leader/mentor to guide/advice you

Lack of time to participate

Other(Please specify)

*:

From what you experienced during your online group activity, indicate your opinion on the following issues:

\begin{tabular}{|c|c|c|c|c|c|}
\hline & $\begin{array}{c}\text { Strongly } \\
\text { Agree }\end{array}$ & Agree & Neutral & Disagree & $\begin{array}{c}\text { Strongly } \\
\text { Disgree }\end{array}$ \\
\hline $\begin{array}{r}\text { I was } \\
\text { satisfied with } \\
\text { the level of } \\
\text { contact I had } \\
\text { with my } \\
\text { instructor }\end{array}$ & 0 & 0 & 0 & 0 & 0 \\
\hline $\begin{array}{r}\text { I was } \\
\text { satisfied with } \\
\text { the level of } \\
\text { contact I had } \\
\text { with my } \\
\text { peers }\end{array}$ & 0 & 0 & 0 & 0 & 0 \\
\hline $\begin{array}{l}\text { Replies from } \\
\text { peers on my } \\
\text { post/requests } \\
\text { took too long }\end{array}$ & 0 & 0 & 0 & 0 & 0 \\
\hline
\end{tabular}

Briefly describe the worst online experience you have had in an online group activity 
(c) Muuro,Wagacha, Kihoro, Oboko

\section{Athabasca University $\mathbf{Z}$}

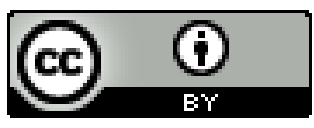

This work is licensed under a Creative Commons Attribution 4.0 International License. 